This is the peer reviewed version of the following article:

Vázquez, J. J., \& Panadero, S. (2019). Suicidal attempts and stressful life events among women in a homeless situation in Madrid (Spain). American journal of orthopsychiatry, 89(2), 304-311, which has been published in final form at:

https://doi.org/10.1037/ort0000387

This article may be used for non-commercial purposes in accordance with American Psychological Association and Conditions for Use of Self-Archived Versions. 
Accepted version of the article:

Vázquez, J. J., \& Panadero, S. (2019). Suicidal attempts and stressful life events among women in a homeless situation in Madrid (Spain). American journal of orthopsychiatry, 89(2), 304-311. DOI: doi.org/10.1037/ort0000387

(C) 2016 American Psychological Association. This paper is not the copy of record and may not exactly replicate the authoritative document published in the APA journal. Please do not copy or cite without authors permission. The final article will be available, upon publication, at: 10.1037/ort0000387.

\title{
SUICIDAL ATTEMPTS AND STRESSFUL LIFE EVENTS AMONG WOMEN IN A HOMELESS SITUATION IN MADRID (SPAIN)
}

\author{
José Juan Vázquez \\ Dept. Social Psychology \\ Universidad de Alcalá \\ Sonia Panadero \\ Dept. Clincal Psychology \\ Universidad Complutense de Madrid
}

Corresponding author: José Juan Vázquez, Ph.D. Área de Psicología Social. Facultad de Documentación. Universidad de Alcalá. Aulario María de Guzmán. C/ San Cirilo, s/n. 28801 Alcalá de Henares. Madrid. España. E-mail: jj.vazquez@uah.es.

Funding statement: This research was supported by the "Agencia Estatal de Investigación" of the "Ministerio de Economía, Industria y Competitividad” of Spain (Ref. FEM2016-75317-R).

Public policy relevance. This study reveals that suicide attempts among women living homeless in Madrid reaches alarming dimensions. Data obtained can be useful for policy makers design programmes for the prevention of suicide in this group. It would be important to designing protocols for the early assessment of suicidal behaviour for their implementation in both assistance services and by street outreach teams. 


\begin{abstract}
The objective of this paper is to analyze the relationship between suffering from stressful life events (SLE) and subsequent suicidal behaviour among women in a homeless situation, examining the differences in the number and characteristics of SLE experienced by attempters and non-attempters. The study was carried out based on the data obtained from a sample of women living homeless in Madrid (Spain) $(\mathrm{n}=138)$. The information was gathered using a structured interview. The results show that $46 \%$ of these women living homeless in Madrid had attempted suicide, and $32 \%$ of them had done so for the first time when they were homeless. We observed a high level of SLE among the women in a homeless situation, with a substantial increase in the number and severity of the stressors suffered by the interviewees who had attempted suicide, both during their childhood and adolescence and in their later lives.
\end{abstract}

Keywords. Homeless women; Suicidal attempts; Stressful life events; Social exclusion; Spain 


\section{Introduction}

In developed societies, people living homeless are one of the most obvious embodiments of the phenomenon of social exclusion (Vázquez, Panadero, Martín, \& Díaz-Pescador, 2015). People in a homeless situation not only live in extreme poverty, but also suffer from high levels of family and social disengagement, and have great difficulties in achieving social/employment reintegration, and significant physical and mental health problems (Vázquez, Panadero \& Zúñiga, 2017a, 2017b, 2018). Women living homeless are in a particularly vulnerable subgroup among people in a homeless situation, and have characteristics, needs and life trajectories that are different from those of their male counterparts (Leonori et al., 2000; Panadero \& Vázquez, 2016). However, the research homeless people from a gender perspective undertaken to date has been very scarce.

Two factors that have attracted particular interest in recent years have been the health difficulties and victimisation experienced by people in a homeless situation, which seem to have a particularly negative impact on women. For example, various studies have highlighted the very high mortality rates among the homeless population (Nordentoft \& Wandall-Holm, 2003; Hwang, Wilkins, Tjepkema, O'Campo, \& Dunn, 2009; Birgenheir, Lai \& Kilbourne, 2013; Nusselder, Slockers, Krol, Slockers, Looman, \& van Beeck, 2013), which could particularly affect women in this situation (Nusselder et al., 2013). Deaths by suicide have rarely been included among the causes of this high mortality rate, although the available data suggest that the real suicide rate among people in a homeless situation may be very high (Babidge, Burich, \& Butler, 2001; Barak, Cohen, \& Aizenberg, 2004). According to Hwang et al. (2009), the probability of suicide among people living homeless could be six times higher than among the general population, and unlike the general population, suicide mortality rates among women in a homeless situation are higher than among men in the same situation.

Various studies have found very high percentages of suicide attempts among people living homeless, although there are major variations in this regard: $13 \%$ of the youth in a homeless situation in California (US) (Petering, et al., 2017); 33-34\% of the people living homeless in Toronto (Canada) (Eynan et al., 2002) and Madrid (Spain) (Panadero, Martín \& Vázquez, 2018); $34 \%$ of the homeless individuals with alcohol problems in Washington (US) (Collins et al., 2016); $15 \%-47 \%$ of the homeless US veterans (Hoffberg et al., 2017); or $42 \%$ of the youth homelessness in Canada (Gaetz, O'Grady, Kidd, \& Schwan, 2016). In cases in which the gender of the participants has been considered, a higher percentage of women living homeless than men have been found to have attempted suicide (Eynan, et al., 2002).

The relationship between the risk of suicide and stressful life events (SLE) - experiences that play a key role in one's life and that frequently causes significant changes for the person involve - is mentioned widely in the scientific literature (e.g. Cheng, Chen, Chen, \& Jenkins, 2000; Foster, Gillespie, McClelland \& Patterson, 1999; Gould, Fisher, Parides, Flory, \& Shaffer, 1996; Heikkinen, Isometsä, Henriksson, Marttunen, Aro, \& Lönnqvist, 1997; Vázquez, Panadero \& Rincón, 2010). Suffering from many SLE, especially if these take place during the early years of life and if they are related to the family environment, seems to be an important vulnerability factor for suicide attempts in the future (Vázquez, Panadero, \& Martín, 2015; Vázquez et al., 2007, 2010).

According to Devries et al. (2011), the risk factors that most consistently predict suicide attempts among women are childhood sexual abuse, intimate partner violence, non-partner physical violence, having been divorced, separated or widowed, and having a mother who experienced 
intimate partner violence. Furthermore, having suffered from physical, psychological and/or sexual abuse during childhood also seems to have a significant impact on vulnerability to engaging in subsequent suicidal behaviour in adult life (Osvath, Vörös, \& Fekete, 2004; Pompili et al., 2011; Vázquez et al., 2010), and Andrews, Corry, Slade, Issakidis, and Swanston (2004) estimated that experiencing sexual abuse during childhood is related to $11 \%$ of suicide attempts among women.

Suffering from SLE is particularly common among groups in situations of poverty and social exclusion, both during childhood and adolescence, and in later life (e.g. Guillén, Panadero, Rivas, \& Vázquez, 2015; Vázquez, Suarez, Berrios, \& Panadero, in press; Vázquez et al., 2007, 2010). Various studies show that a history of physical and/or sexual abuse during childhood (e.g. Beautrais, Joyce, \& Mulder, 1997; Brown, Cohen, Johnson, \& Smailes, 1999; Pompili et al., 2011; Vázquez et al., 2010), and impaired or neglectful parenting (e.g. Beautrais et al., 1997; Brent et al., 1993; Johnson, Cohen, Gould, Kasen, Brown, \& Brook, 2002) are SLE which have especially serious consequences when they are experienced in the early years of life.

Some of these events, such as physical and/or sexual abuse in childhood, appear to be especially common among women in a homeless situation (Zugazaga, 2004; Toro, 2007; Vázquez, Berrios, Bonilla, \& Suarez, in press). Stein, Leslie \& Nyamathi (2002) found that almost one-third $(31 \%)$ of women living homeless had suffered from physical abuse in childhood. A similar phenomenon occurs with sexual abuse, which may have been experienced by more than $40 \%$ of women in a homeless situation (Noell, Rohde, Seeley \& Ochs, 2001; Tyler \& Cauce, 2002). Benda (2005) points out that childhood and current sexual and physical abuses, depression, fearfulness, relationship problems, limited social support, and low self-esteem was more strongly associated with suicidal attempts for homeless women than for homeless men.

Panadero et al. (2018) report that 30.3\% of people living homeless in Madrid report having attempted to commit suicide, and that these people had suffered from more SLE both during their childhood and adolescence and in later life than those who did not carry out suicide attempts. 56.1\% of the attempters had attempted suicide more than once, and in $57.9 \%$ of the cases the first suicide attempt occurred when the person was already homeless. Since women in a homeless situation account for a relatively small percentage of the total number of people living homeless in Spain, hardly any studies have specifically focused on them, despite the fact that they are a particularly vulnerable subgroup (Vázquez et al., 2017b). Given the importance of the issue, the objective of this paper is to study the relationship between suffering from SLE and suicidal behaviour among women living homeless in Madrid (Spain).

\section{Method}

\section{Sample}

The study was carried out with a sample of women living homeless in Madrid, made up of 138 women, who were all adults, who had spent the night before the interview in a shelter or other facility for people in a homeless situation, on the street or in other places not initially designed for sleeping (abandoned buildings, underground railway, next to ATMs, etc.). The main characteristics of the sample are shown in Table 1. 
Table 1. Main characteristics of the women in a homeless situation in Madrid (Spain).

\begin{tabular}{lcc}
\hline Characteristics & n & \% / Mean (SD) \\
\hline Age (M years, SD) & 138 & $45.5(11.38)$ \\
\hline Marital status & 82 & \\
Single & 9 & $59.4 \%$ \\
Married & 28 & $6.5 \%$ \\
Legally separated or divorced & 12 & $20.3 \%$ \\
Separated de facto without legal procedures & 7 & $8.7 \%$ \\
Widow & & $5.1 \%$ \\
\hline Nationality & 90 & \\
Spanish & 42 & $62.5 \%$ \\
Foreign & 6 & $30.4 \%$ \\
Both & & $4.3 \%$ \\
\hline Completed education & 13 & \\
No education & 13 & $9.4 \%$ \\
Incomplete primary education & 45 & $32.0 \%$ \\
Primary education (up to 14 years old) & 26 & $18.8 \%$ \\
Secondary education (up to 18 years old) & 12 & $8.7 \%$ \\
Higher non-university education & 24 & $17.4 \%$ \\
University education & & \\
\hline Has had children & 84 & $60.9 \%$ \\
Yes & 54 & $39.1 \%$ \\
No & 84 & $2.1(1.30)$ \\
Number of children (M children, SD) & 82 & $21.8(5.30)$ \\
Age when the first child was born (M years, SD) & 83 & $2.1(1.21)$ \\
Number of children currently living (M children, SD) & & \\
\hline Slept in one of the following places last month & 16 & $11.4 \%$ \\
In the street & 10 & $7.1 \%$ \\
In an unsuitable place & 113 & $80.7 \%$ \\
In a shelter & 128 & $76.0(90.54)$ \\
\hline Total months homeless adding up all the episodes (M months, SD) & &
\end{tabular}

As shown in Table 1, the vast majority of women in a homeless situation interviewed in Madrid were of Spanish origin, and their mean age was 45 years old. Although $60 \%$ were single, $40.6 \%$ had been married at some point in their lives, although very few were still married at the time of the interview. $22.4 \%$ of the interviewees had not completed primary education, while $17.4 \%$ had completed some form of university education. The women interviewed had been homeless for an average of six years, and the vast majority reported having slept in a shelter during the month prior to the interview.

\section{Procedure}

The women in a homeless situation were interviewed in the street or in other places not initially designed for sleeping $(8.6 \%, 12$ women), in shelters for homeless people $(84.8 \%, 117$ women) and in other facilities providing care for this group (6.5\%, 9 women). Data collection was carried out over a 12-month period. After the objectives of the research and the processing that the data would receive were explained to the participants, they were asked for their informed consent, 
and assured that their anonymity would be respected at all times. Incentives were not offered for participation.

In view of the results obtained in previous studies (Panadero \& Vázquez, 2016), we assumed that a relatively high number of interviewees would have a low or very low level of education, and that the number of women living homeless in Madrid of foreign origin - with potential difficulties with understanding the language - would be relatively high. As a result, a structured interview was used to gather information, which enabled us to circumvent the possible problems arising from the interviewees' difficulties with reading and/or understanding. The interviews lasted between 45 and 80 minutes.

The structured interview included the question: "have you attempted suicide at some point in your life?" with possible response options of "yes" or "no". Those interviewees who indicated that they attempted suicide were asked the following questions: "At what age did you attempted suicide for the first time?", "'How many times did you attempted suicide throughout your life?" and, "Were you in a homeless situation when you attempted suicide for the first time?". We defined a suicide attempt as an "incident accompanied by self-reported intent to die" (Goldman-Mellor et al., 2014; Guillén et al., 2015). When gathering information on the stressful life events (SLE) suffered, and adapted version of the L-SVE was used to do so [Listado de Sucesos Vitales Estresantes para Colectivos en Exclusión Social /List of Stressful Life Events for People in Social Exclusion] (Panadero et al., 2018). The instrument consists of 59 possible SLE: 29 SLE that could have occurred before age 18 (see Table 3 ) and 30 SLE that could have occurred throughout the interviewee's life (see Table 4). The participants had to respond if they had suffered each of the SLE or not (dichotomising answer).

\section{Data analysis}

The database was developed and processed using the SPSS statistical analysis and data management system (version 19.0 for Windows). When making comparisons between the two groups, the $\chi^{2}$ (Chi square) statistic was used for nominal variables, and the "Student t test for independent samples" was used for continuous variables. For stressful life events, the probability of each event was computed between attempters and non-attempters. In univariate analyses, we computed the odds ratios with $95 \%$ confidence intervals by standard methods (Rudas, 1998).

\section{Results}

$46.4 \%$ (65) of the women in a homeless situation interviewed in Madrid answered affirmatively to the question 'Have you attempted suicide at some point in your life?'. $60.0 \%$ (39) of these had attempted suicide on more than one occasion. Among the women living homeless who had attempted suicide (attempters), the first suicide attempt occurred on average when they were 28.13 years old $(\mathrm{SD}=12.287)$. In $32.4 \%$ (33) of the cases, the first attempt occurred when the woman had already become homeless. 
Table 2. Differences in age, time in a homeless situation, and age at which they had had housing problems for the first time between women in a homeless situation in Madrid (Spain) who had attempted suicide (attempters) and those who had not (non-attempters)

\begin{tabular}{lccc}
\hline & $\begin{array}{c}\text { Attempters } \\
(\mathrm{n}=65)\end{array}$ & $\begin{array}{c}\text { Non attempters } \\
(\mathrm{n}=69)\end{array}$ & t \\
\hline Age (M years, SD) & $43.72(10.438)$ & $47.59(12.082)$ & $1.979^{*}$ \\
\hline Time in a homeless situation (M moths, SD) & $99.18(105.203)$ & $52.87(62.566)$ & $-2.914^{* *}$ \\
\hline $\begin{array}{l}\text { Age at which they had housing problems for the } \\
\text { first time (M years, SD) }\end{array}$ & $33.18(12.084)$ & $40.28(16.097)$ & $2.807^{* *}$ \\
\hline
\end{tabular}

As shown in Table 2, the attempters were younger than the non-attempters and reported having spent longer homeless than the non-attempters. The attempters had also had housing problems for the first time at younger ages than the non-attempters. The differences between attempters and non-attempters in terms of suffering from SLE are shown in Tables 3 and 4.

Table 3. Differences in experiencing Stressful Life Events before 18 years old between women in a homeless situation in Madrid (Spain) who had attempted suicide (attempters) and those who had not (nonattempters)

\begin{tabular}{lccccr}
\hline $\begin{array}{l}\text { Stressful life events experienced } \\
\text { before the age of 18 }\end{array}$ & $\begin{array}{c}\text { Attempters } \\
(\mathrm{n}=65)\end{array}$ & $\begin{array}{c}\text { Non } \\
\text { attempters } \\
(\mathrm{n}=69)\end{array}$ & $\chi 2$ & $\begin{array}{l}\text { Odds } \\
\text { ratio }\end{array}$ & $\mathbf{9 5 \%}$ CI \\
\hline Major financial problems & $50.8 \%(33)$ & $23.2 \%(16)$ & $10.977^{* * *}$ & 3.416 & $\begin{array}{r}1.628- \\
7.167\end{array}$ \\
\hline $\begin{array}{l}\text { Prolonged unemployment of a member } \\
\text { of their family }\end{array}$ & $31.3 \%(20)$ & $17.6 \%(12)$ & 3.322 & & \\
\hline $\begin{array}{l}\text { A parent had a physically } \\
\text { incapacitating health problem }\end{array}$ & $38.5 \%(25)$ & $18.8 \%(13)$ & $6.342^{* *}$ & 2.629 & $\begin{array}{r}1.230- \\
5.893\end{array}$ \\
\hline $\begin{array}{l}\text { A parent had a serious mental health } \\
\text { problem }\end{array}$ & $21.5 \%(14)$ & $7.2 \%(5)$ & $5.618^{*}$ & 3.514 & $\begin{array}{r}1.187- \\
10.403\end{array}$ \\
\hline A parent had problems with alcohol & $43.1 \%(28)$ & $18.8 \%(13)$ & $9.258^{* *}$ & 3.260 & $\begin{array}{r}1.498- \\
7.096\end{array}$ \\
\hline A parent had problems with drugs & $16.9 \%(11)$ & $2.9 \%(2)$ & $7.515^{* *}$ & 6.824 & $\begin{array}{r}1.450- \\
32.101\end{array}$ \\
\hline A parent left the family home & $32.3 \%(21)$ & $21.7 \%(15)$ & 1.903 & & \\
\hline $\begin{array}{l}\text { Serious fights and arguments between } \\
\text { the parents }\end{array}$ & $55.4 \%(36)$ & $21.7 \%(15)$ & $16.072^{* * *}$ & 4.469 & $\begin{array}{r}2.106- \\
9.485\end{array}$ \\
\hline Her mother was abused by her partner & $44.6 \%(29)$ & $24.6 \%(27)$ & $5.925^{*}$ & 2.464 & $\begin{array}{r}1.183- \\
5.135\end{array}$ \\
\hline Problems of family violence & $53.8 \%(35)$ & $27.5 \%(19)$ & $9.630^{* *}$ & 3.070 & $\begin{array}{r}1.496- \\
6.301\end{array}$ \\
\hline One of her parents was in prison & $12.5 \%(8)$ & $4.3 \%(3)$ & 2.909 & & \\
\hline
\end{tabular}




\begin{tabular}{|c|c|c|c|c|c|}
\hline $\begin{array}{l}\text { Stressful life events experienced } \\
\text { before the age of } 18\end{array}$ & $\begin{array}{l}\text { Attempters } \\
\quad(\mathrm{n}=65)\end{array}$ & $\begin{array}{c}\text { Non } \\
\text { attempters } \\
(\mathrm{n}=69) \\
\end{array}$ & $\chi^{2}$ & $\begin{array}{l}\text { Odds } \\
\text { ratio }\end{array}$ & $95 \% \mathrm{CI}$ \\
\hline $\begin{array}{l}\text { Serious conflicts between her and } \\
\text { someone in your family }\end{array}$ & $46.9 \%(30)$ & $17.4 \%(12)$ & $13.358 * * *$ & 4.191 & $\begin{array}{r}1.897- \\
9.261\end{array}$ \\
\hline Frequent changes of residence & $24.6 \%(16)$ & $14.5 \%(10)$ & 2.193 & & \\
\hline Thrown out of home & $26.2 \%(17)$ & $11.6 \%(8)$ & $4.675^{*}$ & 2.701 & $\begin{array}{r}1.075- \\
6.787 \\
\end{array}$ \\
\hline She was abandoned & $20.0 \%(13)$ & $8.7 \%(6)$ & 3.515 & & \\
\hline Ran away from home & $52.3 \%(34)$ & $15.9 \%(11)$ & $19.845^{* * *}$ & 5.783 & $\begin{array}{l}2.579- \\
12.970\end{array}$ \\
\hline Parents divorced or separated & $26.6 \%(17)$ & $29.9 \%(20)$ & 0.097 & & \\
\hline $\begin{array}{l}\text { Brought up by people other than their } \\
\text { parents }\end{array}$ & $36.9 \%(24)$ & $27.5 \%(19)$ & 1.353 & & \\
\hline $\begin{array}{l}\begin{array}{l}\text { Housing problems in childhood } \\
\text { (eviction, } \\
\text { inadequate } \\
\text { conditions, overcrowding, etc.) }\end{array} \\
\end{array}$ & $18.5 \%(12)$ & $8.7 \%(6)$ & 2.745 & & \\
\hline Dropped out of school & $43.1 \%(28)$ & $20.3 \%(14)$ & $8.076^{* *}$ & 2.973 & $\begin{array}{r}1.383- \\
6.389 \\
\end{array}$ \\
\hline Expelled from school & $12.3 \%(8)$ & $8.7 \%(6)$ & 0.467 & & \\
\hline Suffered from abuse & $56.9 \%(37)$ & $27.5 \%(19)$ & $11.882 * * *$ & 3.477 & $\begin{array}{r}1.691- \\
7.152 \\
\end{array}$ \\
\hline $\begin{array}{l}\text { Psychological abuse (the abuser } \\
\text { was someone in her family) }\end{array}$ & $46.2 \%(30)$ & $22.1 \%(15)$ & $8.619 * *$ & 3.092 & $\begin{array}{r}1.427- \\
6.428 \\
\end{array}$ \\
\hline $\begin{array}{l}\text { Psychological abuse (the abuser } \\
\text { was someone outside her family) }\end{array}$ & $12.3 \%(8)$ & $4.4 \%(3)$ & 2.731 & & \\
\hline $\begin{array}{l}\text { Physical abuse (the abuser was } \\
\text { someone in her family) }\end{array}$ & $40.0 \%(26)$ & $16.2 \%(11)$ & $9.393 * *$ & 3.455 & $\begin{array}{r}1.530- \\
7.798 \\
\end{array}$ \\
\hline $\begin{array}{l}\text { Physical abuse (the abuser was } \\
\text { someone outside her family) }\end{array}$ & $10.8 \%(7)$ & $5.9 \%(4)$ & 1.046 & & \\
\hline Suffered from sexual abuse & $50.8 \%(33)$ & $10.1 \%(7)$ & $26.379 * * *$ & 9.134 & $\begin{array}{r}3.638- \\
22.930 \\
\end{array}$ \\
\hline By a member of your family & $35.4 \%(23)$ & $7.4 \%(5)$ & $15.712 * * *$ & 6.900 & $\begin{array}{l}2.432- \\
19.579\end{array}$ \\
\hline By someone outside her family & $21.5 \%(14)$ & $2.9 \%(2)$ & $10.681^{* * *}$ & 9.059 & $\begin{array}{r}1.969- \\
41.668\end{array}$ \\
\hline
\end{tabular}

$* \mathrm{p} \leq .05 ; * * \mathrm{p} \leq .01 ; * * * \mathrm{p} \leq .001$

As can be seen in Table 3, during their childhood and adolescence, the attempters had a greater probability of their parents having suffered from significant financial problems, incapacitating illness, mental health problems, problems related to alcohol and in particular, problems related to drug use. In their family environment, the attempters also presented a greater probability of having experienced serious fights and conflicts between their parents, violence in 
the family, serious conflicts with someone in their family, as well their mother being abused by her partner and having experienced psychological abuse and physical abuse themselves (mainly from members of their family). The probability of having suffered from sexual abuse during their childhood and adolescence, by both members of their family and by other people, is very high among the attempters. Finally, the attempters presented a greater probability of having left school at an early age, and a much higher probability of having ran away from the place where they lived. The number of SLE experienced in childhood and adolescence by the attempters was significantly higher than the number suffered by the non-attempters. In that period of their lives, the attempters had suffered on average 8.15 events $(\mathrm{SD}=4.84)$ compared to an average of $3.79(\mathrm{SD}=3.90)$ events suffered by the non-attempters $(\mathrm{t}(115.132)=-5.584 ; \mathrm{p}=.000)$.

Table 4. Differences in experiencing Stressful Life Events at some point in their lives between women in a homeless situation in Madrid (Spain) who had attempted suicide (attempters) and those who had not (non-attempters)

\begin{tabular}{|c|c|c|c|c|c|}
\hline Stressful life events & $\begin{array}{l}\text { Attempters } \\
\quad(\mathrm{n}=65)\end{array}$ & $\begin{array}{c}\text { Non } \\
\text { Attempters } \\
(\mathrm{n}=69)\end{array}$ & $\chi^{2}$ & $\begin{array}{l}\text { Odds } \\
\text { ratio }\end{array}$ & $95 \% \mathrm{CI}$ \\
\hline Death of father & $66.7 \%(42)$ & $66.2 \%(45)$ & 0.004 & & \\
\hline Death of mother & $47.5 \%(20)$ & $46.3 \%(31)$ & 0.021 & & \\
\hline Death of spouse or partner & $26.2 \%(17)$ & $15.9 \%(11)$ & 2.112 & & \\
\hline $\begin{array}{l}\text { Suffered from a serious illness, injury } \\
\text { or accident }\end{array}$ & $69.2 \%(45)$ & $37.7 \%(26)$ & $13.374 * * *$ & 3.721 & $\begin{array}{r}1.816- \\
7.624 \\
\end{array}$ \\
\hline Separation or divorce from spouse & $53.1 \%(34)$ & $44.9 \%(31)$ & 0.893 & & \\
\hline $\begin{array}{l}\text { Suffered from serious unemployment } \\
\text { problems }\end{array}$ & $80.0 \%(52)$ & $79.7 \%(55)$ & 0.002 & & \\
\hline $\begin{array}{llll}\begin{array}{l}\text { Suffered from major financial } \\
\text { problems }\end{array} & & \\
\end{array}$ & $89.2 \%(58)$ & $82.6 \%(57)$ & 1.206 & & \\
\hline $\begin{array}{l}\text { Drunk too much at some point in her } \\
\text { life }\end{array}$ & $47.7 \%(31)$ & $24.6 \%(17)$ & $7.738^{* *}$ & 2.789 & $\begin{array}{r}1.340- \\
5.802 \\
\end{array}$ \\
\hline Abused drugs at some point in her life & $58.5 \%(38)$ & $17.4 \%(12)$ & $24.136 * * *$ & 6.685 & $\begin{array}{l}3.021- \\
14.731\end{array}$ \\
\hline Been in prison & $35.47 \%(23)$ & $11.6 \%(8)$ & $10.653 * * *$ & 4.176 & $\begin{array}{l}1.706- \\
10.223 \\
\end{array}$ \\
\hline Admitted to a psychiatric hospital & $40.4 \%(26)$ & $18.8 \%(13)$ & $7.263^{* *}$ & 2.872 & $\begin{array}{r}1.315- \\
6.273 \\
\end{array}$ \\
\hline $\begin{array}{l}\text { Done work that separated her from her } \\
\text { home }\end{array}$ & $27.3 \%(18)$ & $47.8 \%(33)$ & $5.755^{*}$ & 0.418 & $\begin{array}{r}0.203- \\
0.858 \\
\end{array}$ \\
\hline Lost her home due to eviction & $21.5 \%(14)$ & $18.8 \%(13)$ & 0.151 & & \\
\hline Emigrated from her country of origin & $40.0 \%(16)$ & $55.1 \%(38)$ & 3.084 & & \\
\hline $\begin{array}{l}\text { Left her partner and/or children in } \\
\text { their place of origin }\end{array}$ & $15.4 \%(10)$ & $26.1 \%(18)$ & 2.319 & & \\
\hline
\end{tabular}




\begin{tabular}{|c|c|c|c|c|c|}
\hline Stressful life events & $\begin{array}{l}\text { Attempters } \\
\quad(\mathrm{n}=65)\end{array}$ & $\begin{array}{c}\text { Non } \\
\text { Attempters } \\
(\mathrm{n}=69)\end{array}$ & $\chi^{2}$ & $\begin{array}{l}\text { Odds } \\
\text { ratio }\end{array}$ & $95 \% \mathrm{CI}$ \\
\hline Had a serious mental health problem & $50.8 \%(33)$ & $27.5 \%(19)$ & $7.608 * *$ & 2.714 & $\begin{array}{r}1.324- \\
5.564 \\
\end{array}$ \\
\hline $\begin{array}{l}\text { Suffered from sexual assault (over } 18 \\
\text { years old) }\end{array}$ & $45.3 \%(29)$ & $21.7 \%(15)$ & $8.335^{* *}$ & 2.938 & $\begin{array}{r}1.403- \\
6.344\end{array}$ \\
\hline $\begin{array}{l}\text { Suffered from sexual assaults } \\
\text { (after } 18 \text { years old) by her } \\
\text { partner }\end{array}$ & $20.3 \%(13)$ & $10.1 \%(7)$ & 2.687 & & \\
\hline $\begin{array}{l}\text { Suffered from sexual assaults } \\
\text { (after } 18 \text { years old) by a relative }\end{array}$ & $6.3 \%(4)$ & $1.4 \%(1)$ & 2.115 & & \\
\hline $\begin{array}{l}\text { Suffered from sexual assaults } \\
\text { (after } 18 \text { years old) by someone } \\
\text { else }\end{array}$ & $29.7 \%(45)$ & $13.0 \%(9)$ & $5.534 *$ & 2.815 & $\begin{array}{r}1.165- \\
6.802\end{array}$ \\
\hline $\begin{array}{l}\text { Suffered from abuse by her spouse or } \\
\text { partner }\end{array}$ & $70.8 \%(46)$ & $44.9 \%(31)$ & $9.144 * *$ & 2.968 & $\begin{array}{r}1.452- \\
6.064 \\
\end{array}$ \\
\hline Suffered from physical violence & $67.7 \%(44)$ & $39.1 \%(27)$ & $10.961 * * *$ & 3.259 & $\begin{array}{r}1.603- \\
6.629\end{array}$ \\
\hline Has been reported to the police & $50.8 \%(33)$ & $20.3 \%(14)$ & $13.654 * * *$ & 4.051 & $\begin{array}{r}1.891- \\
8.680\end{array}$ \\
\hline $\begin{array}{l}\text { Has been arrested or detained for a } \\
\text { crime }\end{array}$ & $56.9 \%(37)$ & $20.3 \%(14)$ & $19.053^{* * *}$ & 5.191 & $\begin{array}{l}2.416- \\
11.156\end{array}$ \\
\hline Has been convicted of a crime & $36.9 \%(24)$ & $13.0 \%(9)$ & $10.282 * * *$ & 3.902 & $\begin{array}{r}1.647- \\
9.249\end{array}$ \\
\hline Became pregnant without wishing to & $65.1 \%(41)$ & $33.3 \%(23)$ & $13.288^{* * *}$ & 3.727 & $\begin{array}{r}1.814- \\
7.650\end{array}$ \\
\hline Underwent an abortion & $42.2 \%(27)$ & $30.4 \%(21)$ & 1.988 & & \\
\hline Suffered from a miscarriage & $31.3 \%(20)$ & $18.8 \%(13)$ & 2.741 & & \\
\hline $\begin{array}{l}\text { Separation from a child (adoption, } \\
\text { abandoned, etc.) }\end{array}$ & $47.7 \%(31)$ & $18.8 \%(13)$ & $12.633^{* * *}$ & 3.928 & $\begin{array}{r}1.809- \\
8.527\end{array}$ \\
\hline $\begin{array}{l}\text { She was a single mother (without a } \\
\text { partner) }\end{array}$ & $24.6 \%(16)$ & $17.4 \%(12)$ & 1.057 & & \\
\hline
\end{tabular}

$* \mathrm{p} \leq .05 ; * * \mathrm{p} \leq .01 ; * * * \mathrm{p} \leq .001$

As shown in Table 4, the women in a homeless situation who had attempted suicide presented a greater probability of having suffered from legal problems during their lives (reported to police, arrests, convictions and prison incomes), problems arising from the excessive consumption of alcohol and above all, problems arising from drug use. Likewise, the attempters presented a greater probability than the non-attempters of having suffered from illnesses, injuries or accidents, serious mental health problems and/or admission to psychiatric hospitals. The attempters also presented a greater probability of having suffered from sexual assaults, physical violence and/or abuse by their partner, as well as having had unwanted pregnancies and/or having 
been forced to separate from one of their children. Meanwhile, among the non-attempters there is a greater probability of having done jobs or employment that took them away from their home. As for the total number of SLE experienced, during their lives the attempters had suffered from a mean of 20.96 events $(\mathrm{SD}=6.35)$, while among the non-attempters, this mean figure was $12.69(\mathrm{SD}=$ 6.38) $(\mathrm{t}(114)=-6.94 ; \mathrm{p}=.000)$.

\section{Conclusions and discussion}

There is a very high rate of suicide attempts among women living homeless in Madrid, to the extent that almost half (46\%) reported having attempted suicide. This percentage is much higher than that observed among people living homeless in Madrid as a whole (mainly males), in which $30 \%$ of the interviewees reported having attempted suicide (Panadero et al., 2018). The data observed, which are consistent with those reported by other authors (Eynan, et al., 2002), show the seriousness of the problem posed by the high rate of suicide attempts among people in a homeless situation, which is particularly high among women in that situation.

The fact that $46 \%$ of the women living homeless in Madrid said they had tried to commit suicide at some point is a source of particular concern when the data is compared with the percentage of people who have attempted suicide among the Spanish population as a whole - 1.5\% (Gabilondo et al., 2007), among women in the population as a whole - 1-8\% in different countries (e.g. Borges et al., 2007; Gureje, Kola, Uwakwe, Udofia, Wakil, \& Afolabi, 2007; Joe, Stein, Seedat, Herman, \& Williams, 2008; Nock, Borges, Bromet, Cha, Kessler, \& Lee, 2008; Thanh, Tran, Jiang, Leenaars, \& Wasserman, 2006), among people at risk of social exclusion in Madrid 18\% (Panadero \& Vázquez, 2016), and among people living homeless in Madrid - 30\% (Panadero et al., 2018). As the level of difficulty or social exclusion in which the individuals find themselves increases, the percentage of people who report having attempted suicide increases considerably, and this is especially pronounced among women.

The first suicide attempts among women in a homeless situation occurred at an average age of 28 years old, and $60 \%$ reported having attempted suicide on more than one occasion. In contrast to the women interviewed who were non-attempters, the attempters had been homeless for longer - considering all the episodes in total - and had first encountered housing problems at younger ages. Two-thirds of the women living homeless interviewed tried to commit suicide for the first time before becoming homeless, in contrast to people living homeless in Madrid (mainly males), among whom 58\% tried to commit suicide for the first time after becoming homeless (Panadero et al., 2018). Women therefore have a greater tendency to engage in suicidal behaviour before becoming homeless, while men tend to engage in this behaviour after becoming homeless. As discussed below, the women interviewed had suffered many and serious SLE from very early ages, which may have especially serious consequences throughout life (Beautrais, et al., 1997; Brown et al., 1999; Brent et al., 1993; Johnson et al., 2002; Pompili et al., 2011; Vázquez et al., 2010), including a high vulnerability to become homeless, with social uprooting and feelings of hopelessness (Vázquez et al., 2017a, 2017b, 2018). In this difficult situation, before become homeless a high percentage of the women interviewed indicated that they had carried out suicide attempts, although it is not possible to establish a causal relationship between commit suicide attempts and becoming homeless. 
Meanwhile, as reported by various studies (Guillén et al., 2015; Lantz, House, Mero, \& Williams, 2005; Vázquez et al., 2007, 2010, 2015, in press), people living in poverty and/or social exclusion are at increased risk of suffering from SLE, of great intensity and in large quantities, during both childhood and adolescence and throughout their lives. Furthermore, women living homeless in Madrid suffer from many SLE throughout their lives. As well as this situation, which is a concern in itself, there is the finding that the number of SLE experienced is substantially higher among women in a homeless situation who had attempted suicide.

SLE hinder the social inclusion processes of the most disadvantaged groups (Vázquez \& Panadero, 2016; Vázquez et al., in press), and seem to have a negative impact on vulnerability to engaging in suicidal behaviour. The results of this study seem to point in this direction: although women living homeless in general have experienced many SLE both during their childhood and adolescence as well as in their adult life, these appear to have had a more important effect on those who had engaged in suicidal behaviour. In line with the observations in various studies (e.g. Beautrais et al., 1997; Cooper, Appleby, \& Amos, 2002; Kaslow et al., 2005; Osvath et al., 2004; Pompili et al., 2011), among women living homeless in Madrid, suffering from many SLE seems to be an important vulnerability factor for subsequent suicidal behaviour, especially when these SLE occur during the early years of life and are related to the family environment (Vázquez et al., 2010).

Among the women living homeless interviewed, more attempters reported having lived in dysfunctional family environments during their childhood and adolescence (with serious fights and conflicts between family members and one of their parents suffering from mental health problems, problems with alcohol and/or drugs or disabling diseases), suffering from significant financial problems to a greater extent, running away from home more often and dropping out of school. Likewise, during their childhood and adolescence the attempters experienced serious conflicts with members of their family and violence in their family environment to a greater extent, witnessed their mother suffering from abuse, and suffered from psychological and physical abuse (mainly by members of their family) and sexual violence to a greater extent. According to the results reported by various authors, both a history of physical and/or sexual abuse during childhood (Beautrais et al., 1997; Brown et al., 1999; Devries et al., 2011; Pompili et al., 2011; Vázquez et al., 2010), and impaired or neglectful parenting (Brent et al., 1993; Beautrais et al., 1997; Johnson et al., 2002) or having a mother who had experienced intimate partner violence (Devries et al., 2011) are SLE that are particularly closely related to engaging in subsequent suicidal behaviour in adult life among women living homeless in Madrid.

The women in a homeless situation interviewed who had tried to commit suicide were on average younger than the non-attempters, although they reported having suffered from more SLE during their lives. In specific terms, the attempters were more likely to have used psychoactive substances (alcohol and/or drugs) and had suffered to a greater extent from illnesses, injuries or accidents, serious mental health problems and admissions to psychiatric hospitals. These data are consistent with those reported by Benda (2005) and Rodell, Benda, \& Rodell (2003), who linked suicidal behaviour among the people in a homeless situation with the consumption of psychoactive substances, suffering from mental health problems and psychiatric comorbidity with substance abuse. Likewise, a large percentage of the women living homeless interviewed in Madrid who had tried to commit suicide had suffered from sexual assault, physical violence and/or abuse by their partner. Benda (2005) and Devries et al. (2011) report that suffering from sexual and physical abuse 
and intimate partner violence are among the risk factors that most consistently predict suicide attempts among women. Finally, we also observed that the attempters had suffered from more problems with the law (complaints, arrests, convictions and time spent in prison), had had more unwanted pregnancies and had been forced to separate from some of their children.

Although the scientific literature highlights the existence of a significant relationship between suicidal behaviours and suffering from SLE linked to problems in interpersonal relationships (Brent et al.; 1993; Osvath et al., 2004), separation or divorce from the partner (Devries et al., 2011) or a lack of social support and interpersonal conflicts (Pompili et al., 2011; Weyrauch, Roy-Byrne, Katon, \& Wilson, 2001), differences in this respect between attempters and non-attempters were not observed in this study.

Finally, among the women living homeless in Madrid there is a greater probability among non-attempters to have had jobs or employment that took them away from their home. In Madrid, Spain (Panadero et al., 2018) and Bilbao, Spain (Navarro-Lashayas \& Eiroa-Orosa, 2017), it has been observed that although immigrants living homeless are subject to multiple SLE and reported suicidal behaviour to a greater extent than the Spanish population in general (Gabilondo et al., 2017), the figure is substantially lower than the percentage of people who have attempted suicide among adult homeless people reported in other studies (Eynan et al., 2002). Meanwhile, Spallek et al. (2015) found that the majority of immigrant groups in Europe did not present a higher probability of suicide than the local-born population, and some groups were even at substantially lower probability.

The study has several limitations, since it is a preliminary analysis. Such as, information on suicide attempts was collected using a single question, and we relied on self-reports which were not confirmed by external sources. Also, it is not possible to determine exactly the number and characteristics of women that eventually chose not to participate in the study, since the women contacted who declined to participate were repeatedly invited to take part in the research by different researchers and in several places: street, shelters, or other facilities providing care for people living homeless. Moreover, it is a cross-sectional study design, so caution must be taken when attempting to establish causal relationships. In addition, it should be noted that the study is limited to Madrid, Spain, which makes it difficult to generalize the results to other contexts.

The results obtained emphasise that suffering from certain SLE during childhood, adolescence or adulthood can be an important vulnerability factor for subsequent suicidal behaviour. According to Panadero et al. (2018), reducing the impact of SLE, especially during the earliest stages of life, can influence a decrease in suicide attempts. Given that women in situations of difficulty or social exclusion are exposed to quantitatively very numerous and qualitatively very serious experiences of SLE, and occur at young ages (Panadero et al., 2018), it is important to pay special attention to the development of protocols of early-on assessment of suicidal behaviours aimed at these groups. In the case of women living homeless in Madrid, the suicide attempts rates reaches alarming dimensions, underlining the relevance of implementing programs for the prevention of suicide in this group. To do so, according to Panadero et al. (2018), it would be important to offer training aimed at the detection and prevention of suicidal behaviours to the professionals working with people in a homeless situation, as well as designing protocols for the early assessment of suicidal behaviour for their implementation in both assistance services and by street outreach teams. 


\section{References}

Andrews, G., Corry, J., Slade, T., Issakidis, C., Swanston, H. (2004). Child sexual abuse. In Ezzati, M., Lopez, A. D., Rodgers, A., \& Murray, C. J. L. (Eds). Comparative quantification of health risks: Global and regional burden of disease attributable to selected major risk factors. Geneva: World Health Organization.

Babidge, N.C., Burich, N. \& Butler, T. (2001). Mortality among homeless people with schizophrenia in Sydney, Australia: a 10-year follow-up. Acta Psychiatrica Scandinavica, 9, 105-110. DOI: doi.org/10.1034/j.1600-0447.2001.00192.x

Barak, Y., Cohen, A., \& Aizenberg, D. (2004). Suicide among the homeless: a 9-year case-series analysis. Crisis, 25 (2), 51-3. DOI: dx.doi.org/10.1027/0227-5910.25.2.51

Beautrais, A.L., Joyce P.R., \& Mulder, R.T. (1997). Precipitating factors and life events in serious suicide attempts among youths aged 13 to 24 years. Journal of the American Academy of Child and Adolescent Psychiatry, 36, 1543-1551. DOI: 10.1016/S0890-8567(09)66563-1

Benda, B.B. (2005). Gender differences in predictors of suicidal thoughts and attempts among homeless veterans that abuse substances. Suicide and Life-Threatening Behavior, 35(1), 106116. DOI: $10.1521 /$ suli.35.1.106.59262

Birgenheir D.G., Lai, Z., \& Kilbourne, A.M. (2013). Datapoints: trends in mortality among homeless VA patients with severe mental illness. Psychiatric Services, 64, 7, 608. DOI: 10.1176/appi.ps.201300026.

Borges, G., Nock, M. K., Medina-Mora, M. E., Benjet, C., Lara, C., Chiu, W. T., \& Kessler, R. C. (2007). The Epidemiology of Suicide-Related Outcomes in Mexico. Suicide and LifeThreatening Behavior, 37(6), 627-640. DOI: doi.org/10.1521/suli.2007.37.6.627

Brent, D.A., Perper, J.A., Moritz, G., Baugher, M., Roth, C., Balach, L., \& Schweers, J. (1993). Stressful life events, psychopathology, and adolescent suicide: A case control study. Suicide and Life-Treatening Behaviour, 23, 179-187. DOI: 10.1111/j.1943-278X.1993.tb00178.x

Brown, J., Cohen, P., Johnson, J.G., \& Smailes, E.M. (1999). Childhood abuse and neglect: Specificity of effects on adolescents and young adult depression and suicidality. Journal of the American Academy of Child and Adolescent Psychiatry, 38, 1490-1496. DOI: 10.1097/00004583-199912000-00009

Collins, S. E., Taylor, E. M., King, V. L., Hatsukami, A. S., Jones, M. B., Lee, C., . . Nelson, L. A. (2016). Suicidality among chronically homeless people with alcohol problems attenuates following exposure to housing first. Suicide and Life-Threatening Behavior, 46(6), 655-663. DOI: http://dx.doi.org.bucm.idm.oclc.org/10.1111/sltb.12250

Cheng, A.T., Chen, T.H., Chen, C.C., \& Jenkins, R. (2000). Psychosocial and psychiatric risk factors for suicide. Case-control psychological autopsy study. The British Journal of Psychiatry, 177, 360-365. DOI: 10.1192/bjp.177.4.360

Cooper, J., Appleby, L., \& Amos, T. (2002). Life events preceding suicide by young people. Social Psychiatry and Psychiatric Epidemiology, 37, 271-275. DOI: 10.1007/s001270200019

Devries, K., Watts, C., Yoshihama, M., Kiss, L., Schraiber, L. B., Deyessa, N., ... \& Berhane, Y. (2011). Violence against women is strongly associated with suicide attempts: evidence from 
the WHO multi-country study on women's health and domestic violence against women. Social science \& medicine, 73(1), 79-86. DOI: doi.org/10.1016/j.socscimed.2011.05.006.

Eynan, R., Langley, J., Tolomiczenko, G., Rhodes, A. E., Links, P., Wasylenki, D., \& Goering, P. (2002). The association between homelessness and suicidal ideation and behaviors: Results of a cross-sectional survey. Suicide and Life-Threatening Behavior, 32(4), 418-427. DOI: 10.1521/suli.32.4.418.22341

Foster, T., Gillespie, K., McLelland, R., \& Patterson, C. (1999). Risk factors for suicide independent of DSM-III-R Axis I disorder: Case-control psychological autopsy study in Northern Ireland. The British Journal of Psychiatry, 175(2), 175-179. DOI: doi.org/10.1192/bjp.175.2.175

Gabilondo, A., Alonso, J., Pinto-Meza, A., Vilagut, G., Fernández, A., Serrano-Blanco, A., ... \& Haro, J. M. (2007). Prevalencia y factores de riesgo de las ideas, planes e intentos de suicidio en la población general española. Resultados del estudio ESEMeD [Prevalence and risk factors for suicide ideation, plans and attempts in the Spanish general population. results from the ESEMeD study]. Medicina Clínica, 129, 494-500. DOI: dx.doi.org/10.1157/13111370

Goldman-Mellor, S.J., Caspi, A., Harrington, H., Hogan, S., Nada-Raja, S., Poulton, R., \& Moffitt, T.E. (2014). Suicide attempt in young people: A signal for long-term health care and social needs. JAMA psychiatry, 71(2), 119-127. DOI: 10.1001/jamapsychiatry.2013.2803

Gould, M. S., Fisher, P., Parides, M., Flory, M., \& Shaffer, D. (1996). Psychosocial risk factors of child and adolescent completed suicide. Archives of general psychiatry, 53(12), 1155-1162. DOI:10.1001/archpsyc.1996.01830120095016

Guillén, A.I, Panadero, S., Rivas, E., \& Vázquez, J.J. (2015). Suicide attempts and stressful life events among female victims of intimate partner violence living in poverty in Nicaragua. Scandinavian Journal of Psychology, 56, 349-356. DOI: 10.1111/sjop.12207.

Gureje, O., Kola, L., Uwakwe, R., Udofia, O., Wakil, A., \& Afolabi, E. (2007). The profile and risks of suicidal behaviours in the Nigerian Survey of Mental Health and Well-Being. Psychological Medicine, 37(6), 821-830. DOI: doi.org/10.1017/S0033291707000311.

Heikkinen, A., Isometsä, E., Henriksson, M., Marttunen, M., Aro, H., \& Lönnqvist, J. (1997). Psychosocial factors and completed suicide in personality disorders. Acta Psychiatrica Scandinavica, 95, 49-57. DOI: 10.1111/j.1600-0447.1997.tb00373.x

Hoffberg, A. S., Spitzer, E., Mackelprang, J. L., Farro, S. A., \& Brenner, L. A. (2017). Suicidal self-directed violence among homeless us veterans: A systematic review. Suicide and LifeThreatening Behavior. DOI: http://dx.doi.org.bucm.idm.oclc.org/10.1111/sltb.12369

Hwang, S. W., Wilkins, R., Tjepkema, M., O’Campo, P. J., \& Dunn, J. R. (2009). Mortality among residents of shelters, rooming houses, and hotels in Canada: 11 year follow-up study. BMJ, 339, b4036. DOI: doi.org/10.1136/bmj.b4036.

Gaetz, S. A., O'Grady, B., Kidd, S., \& Schwan, K. (2016). Without a home: The national youth homelessness survey. Toronto: Canadian Observatory on Homelessness Press.

Joe, S., Stein, D. J., Seedat, S., Herman, A., \& Williams, D. R. (2008). Non-fatal suicidal behavior among South Africans. Social Psychiatry and Psychiatric Epidemiology, 43(6), 454-461. 
Johnson, J.G., Cohen, P., Gould, M.S., Kasen, S., Brown, J., \& Brook, J.S. (2002). Childhood adversities, interpersonal difficulties, and risk for suicide attempts during late adolescence and early adulthood. Archives of General Psychiatry, 59, 741-749. DOI:10.1001/archpsyc.59.8.741

Kaslow, N.J., Sherry, A., Bethea, K., Wyckoff, S., Compton, M.T., Bender Grall, M., Scholl, L., Price, A.W., Kellermann, A., Thompson, N., \& Parker, R. (2005). Social risk and protective factors for suicide attempts in low income African American men and women. Suicide LifeThreatening Behavior. 35(4), 400-12. DOI: 10.1521/suli.2005.35.4.400

Lantz, P.M., House, J.S., Mero, R.P., \& Williams, D.R. (2005). Stress, life events, and socioeconomic disparities in health: Results from the American's Changing Lives Study. Journal of Health and Social Behaviour, 46, 274-88.

Leonori, L; Muñoz, M; Vázquez, C; Vázquez, J.J; Bravo, M; Nuche, M; Brandt, P; Bento A. \& Horenbek, B. (2000). The mental health and social exclusion European network: A research activity report on European homeless citizens. European Psychologist, 5(3), 245-251. Doi: 10.1027//1016-9040.5.3.245.

Navarro-Lashayas, M.A., \& Eiroa-Orosa, F.J. (2017). Substance use and psychological distress is related with accommodation status among homeless immigrants. American Journal of Orthopsychiatry, 87(1), 23-33. DOI: dx.doi.org/10.1037/ort0000213

Nock, M. K., Borges, G., Bromet, E. J., Cha, C. B., Kessler, R. C., \& Lee, S. (2008). Suicide and suicidal behavior. Epidemiologic reviews, 30(1), 133-154. DOI: doi.org/10.1093/epirev/mxn002

Noell J., Rohde, P., Seeley, J., \& Ochs, L. (2001). Childhood sexual abuse, adolescent sexual coercion and sexually transmitted infection acquisition among homeless female adolescents. Child Abuse \& Neglect, 25, 1, 137-48. DOI: doi.org/10.1016/S0145-2134(00)00223-4

Nordentoft, M. \& Wandall-Holm, N. (2003). 10 year follow up study of mortality among users of hostels for homeless people in Copenhagen. BMJ, 327, 81. DOI: doi.org/10.1136/bmj.327.7406.81

Nusselder, W.J., Slockers, M.T., Krol, L., Slockers, C.T., Looman, C.W., \& van Beeck, E.F. (2013). Mortality and life expectancy in homeless men and women in Rotterdam. PLoS One, 8, 10, 2001-2010. DOI: 10.1371/journal.pone.0073979

Osvath, P., Vörös, V., \& Fekete, S. (2004). Life events and psychopathology in a group of suicide attempters. Psychopathology, 37, 36-40. DOI: 10.1159/000077018

Panadero, S., Martín, R.M., \& Vázquez, J.J. (2018). Suicide attempts and stressful life events among homeless people in Madrid (Spain). Journal of Community and Applied Social Psychology, 28(4), 200-212. DOI: 10.1002/casp.2351.

Panadero, S. \& Vázquez, J.J. (2016). En las fronteras de la ciudadanía. Situación de las personas sin hogar y en riesgo de exclusión social en Madrid [On the borders of citizenship. Situation of the homeless and at risk of social exclusion in Madrid]. Alcalá de Henares: Universidad de Alcalá. 
Petering, R., Rhoades, H., Winetrobe, H., Dent, D., \& Rice, E. (2017). Violence, trauma, mental health, and substance use among homeless youth juggalos. Child Psychiatry and Human Development, 48(4), 642-650. DOI: http://dx.doi.org.bucm.idm.oclc.org/10.1007/s10578016-0689-5

Pompili, M., Innamorati, M., Szanto, K., Di Vittorio, C., Conwell, Y., Lester, D., \& Amore, M. (2011). Life events as precipitants of suicide attempts among first-time suicide attempters, repeaters, and non-attempters. Psychiatry Research, 186, 300-305. DOI: 10.1016/j.psychres.2010.09.003.

Rodell, D.E., Benda, B.B., \& Rodell, L. (2003). Suicidal thoughts among homeless alcohol and other drug abusers. Alcoholism Treatment Quarterly, 21(2), 57-74. DOI: dx.doi.org/10.1300/J020v21n02_04

Rudas, T. (1998). Odds ratios in the analysis of contingency tables. London: SAGE Publications.

Spallek, J., Reeske, A., Norredam, M., Nielsen, S., Lehnhardt, J., et al. (2015). Suicide among immigrants in Europe. A systematic literature review. European Journal of Public Health, 25 (1), 63-71. DOI: doi.org/10.1093/eurpub/cku121

Stein, J.A., Leslie, M.B., \& Nyamathi, A. (2002). Relative contributions of parent substance use and childhood maltreatment to chronic homelessness, depression, and substance abuse problems among homeless women: Mediating roles of selfesteem and abuse in adulthood. Child Abuse \& Neglect, 26, 1011-1027. DOI: doi.org/10.1016/S0145-2134(02)00382-4

Thanh, H. T. T., Tran, T. N., Jiang, G. X., Leenaars, A., \& Wasserman, D. (2006). Life time suicidal thoughts in an urban community in Hanoi, Vietnam. BMC Public Health, 6(1), 76. DOI: doi.org/10.1186/1471-2458-6-76

Toro, P. (2007) Toward an International Understanding of Homelessness. Journal of Social Issues, 63, 3, 461-481. DOI: doi.org/10.1111/j.1540-4560.2007.00519.x

Tyler, K.A. \& Cauce, A.M. (2002). Perpetrators of early physical and sexual abuse among homeless and runaway adolescents. Child Abuse \& Neglect, 26, 12, 1261-74. DOI: doi.org/10.1016/S0145-2134(02)00413-1

Vázquez, J.J., Berrios, A., Bonilla, E., \& Suarez, A. (in press). Homeless people in León (Nicaragua). Conceptualizing and measuring homelessness in a developing country. American Journal of Orthopsychiatry. DOI: dx.doi.org/10.1037/ort0000336.

Vázquez, J.J. \& Panadero, S. (2016). Chronicity and pseudo inheritance of social exclusion: Differences according to the poverty of the family of origin among trash pickers in León (Nicaragua). Human Rights Quarterly, 38(2), 379-390. DOI: 10.1353/hrq.2016.0037.

Vázquez, J.J., Panadero, S., \& Martín, R.M. (2015). Regional and national differences in stressful life events: The role of cultural factors, economic development, and gender. American Journal of Orthopsychiatry, 85(4), 392-396. DOI: dx.doi.org/10.1037/ort0000029.

Vázquez, J.J., Panadero, S., Martín, R.M., \& Díaz-Pescador, V. (2015). Access to new information and communication technologies among homeless people in Madrid (Spain). Journal of Community Psychology, 43(3), 338-347. DOI: 10.1002/jcop.21682. 
Vázquez, J.J., Panadero, S., \& Rincón, P. (2007). Stressful life events in countries of differing economic development: Nicaragua, Chile, and Spain. Psychological Reports, 101, 193-201. DOI: $10.2466 /$ PR0.101.1.193-201.

Vázquez, J.J., Panadero, S., \& Rincón, P. (2010). Stressful life events and suicidal behaviour in countries with different development levels: Nicaragua, El Salvador, Chile and Spain. Journal of Community and Applied Social Psychology, 20(4), 288-298. DOI: $10.1002 /$ casp.1036.

Vázquez, J.J., Panadero, S., \& Zúñiga, C. (2017a). Content and uniformity of stereotypes and metastereotypes of homeless people in Madrid (Spain). Journal of Community Psychology, 45(1), 128-137. DOI: $10.1002 /$ jcop.21836

Vázquez, J.J., Panadero, S., \& Zúñiga, C. (2017b). Actors, observers, and causal attributions of homelessness: Differences in attribution for the causes of homelessness among domiciled and homeless people in Madrid. American Journal of Orthopsychiatry, 87(1), 15-22. DOI: dx.doi.org/10.1037/ort0000130.

Vázquez, J.J., Panadero, S., \& Zúñiga, C. (2018). Attributions about homelessness in homeless and domiciled people in Madrid, Spain: «Why are they homeless people?». American Journal of Orthopsychiatry, 88(2), 236-247. DOI: dx.doi.org/10.1037/ort0000246

Vázquez, J.J., Suarez, A., Berrios, A., \& Panadero, S. (in press). Stressful life events among homeless people in León (Nicaragua): Quantity, Types, Timing, and Perceived Causality. Journal of Community Psychology. DOI: doi.org/10.1002/jcop.22102.

Weyrauch, K. F., Roy-Byrne, P., Katon, W., \& Wilson, L. (2001). Stressful life events and impulsiveness in failed suicide. Suicide and Life-Threatening Behavior, 31(3), 311-319. DOI: doi.org/10.1521/suli.31.3.311.24240

Zugazaga, C. (2004) Stressful Life Event Experiences of Homeless Adults: A Comparison of Single Men, Single Women, and Women with Children. Journal of Community Psychology, 32, 643-654. DOI: doi.org/10.1002/jcop.20025. 